\title{
Leucine-Rich Repeat-Containing G-Protein Coupled Receptor 5 Staining Method
}

National Cancer Institute

\section{Source}

National Cancer Institute. Leucine-Rich Repeat-Containing G-Protein Coupled Receptor 5

Staining Method. NCl Thesaurus. Code C122840.

An immunohistochemical technique used to detect the presence of leucine-rich repeat-

containing G-protein coupled receptor 5 in a tissue sample. 